\title{
Framing in Russian TV News: How to Shape Reality?
}

\author{
Galina Lukyanova* \\ St.Petersburg State University, 7/9 Universitetskaya nab., St. Petersburg, 199034 Russia
}

\begin{abstract}
In a democratic society, the mass media play an enormous role, as they broadcast various points of view that exist in the society. By using various media effects, authors of information messages influence the formation of certain attitude to a particular political event reflected in the media, thus contributing to the legitimation or de-legitimation of political power. The purpose of this study is to examine the news on Russian federal television channels in order to identify frames that play a role in the process of political power legitimation. Qualitative content analysis shows that media framing is actively used by leading state TV channels as a technology for legitimizing the power. The most frequently used frames are "the Great Power," "Ineptitude of Other Countries," "Confrontation / Opposition," "International Intervention," and "the Strong Leader."
\end{abstract}

\section{Introduction}

The problem of identification, interpretation and evaluation of socio-political factors that influence legitimation or de-legitimation of power is one of the most pressing problems in political science. This topic is becoming increasingly important due to the fact that the development of information and communication technologies results in higher level of citizen involvement in the political process, and, therefore, it is necessary to gain insight into the technologies used to form, maintain or change public opinion. By using various media effects, the authors of information messages influence the formation of a certain attitude to a particular political event reflected in the media, thus contributing to the legitimation or de-legitimation of political power. It should be emphasized that the perception of the significance of any problem depends not only on the number of times that the problem is mentioned but also on the structure of the narrative, which explains the important role of framing in news production and news consumption. By using framing in their reports, mass media, autonomously or together with political actors, are able to shape their own political reality, manipulate public opinion and influence the legitimation or de-legitimation of political power. The aim of this study is to explore the news on Russian federal television channels in order to identify frames that play a role in the process of political power legitimation.

\section{Theoretical background}

Today, framing is defined in numerous ways, but an unambiguous definition of the phenomenon is still lacking. Much intellectual effort has been made in recent years explaining from a variety of perspectives what a frame is, what exactly constitutes framing, how framing works [1-7]. More than a thousand different quotes point at different aspects of this concept, showing them as dominant $[1,8]$. Let us single out the main definitions of framing used in modern literature:

- Frames are organizing principles that are socially shared and persistent over time, that work symbolically to meaningfully structure the social world [9];

- Frames are a central organizing idea for news content that supplies a context and suggests what the issue is through the use of selection, emphasis, exclusion, and elaboration [10];

- Frames are largely unspoken and unacknowledged, organize the world both for journalists who report it and, in some important degree, for us who rely on their reports [11];

- To frame is to select some aspects of a perceived reality and make them more salient in a communicating text, in such a way as to promote a particular problem definition, causal interpretation, moral evaluation, and/or treatment recommendation for the item described [8].

Hallahan [12] defines framing as a critical activity in the construction of social reality because it helps shape the perspectives through which people see the world. The researcher compares a frame with a window or a portrait frame drawn around information that delimits the subject matter and focuses attention on the key elements within [12].

As noted by some researchers, such large number of various definitions of the term makes the study of framing more complicated, despite the universality of the concept for various sciences [2]. At the same time, most definitions of framing support the fact that frames affect cognitive process by determining which memory nodes

Corresponding author: g.lukiyanova@spbu.ru 
and circuits will be activated for the interpretation of a specific message, thus creating a framing effect.

The theory of framing is based on the assumption that the way the problem is covered in the media and the interpretation given to it influences the perception of this problem by the audience. One of the first scholars to study framing in the field of political communication studies was Entman, who described the sociopsychological consequences of framing [13]. In 1991, when studying differences in the coverage of two similar events by American media - the crash of a South Korean aircraft shot down by the Soviet Air Force in 1983 and of the Iranian aircraft shot down by the US Navy in 1987 - the author concludes that these events were presented with different judgements: as an act of violence and as an accident, respectively. Publications on these events had an obvious impact on public opinion in the US, raising the level of mistrust to the USSR and reinforcing support for US foreign policy [13].

Entman [14] argues that messages broadcasted by mass media influence public opinion to a great extent. However, the researcher concludes that one cannot completely change the position of an individual only by the use of broadcast messages, but it is possible to determine the recipient's thought vector by selecting information and method of its presentation. Entman notes that conclusions cannot be prescribed, but they may be imposed with the use of various media effects [14]. The system of schemes that organize the thinking of an individual contains beliefs, attitudes, values and preferences, along with rules for connecting various ideas, and, in their turn, schemes force an individual to pay attention to certain information, help to draw conclusions when information is absent or ambiguous, and contribute to memorization of such information [14].

It should be noted that framing can apply not only to texts but to visual information as well. Television, for example, combines these elements, which reinforces the resulting effect. Frames are found in several types of locations: in communication, in texts, in the consciousness of the recipient and in the culture [8]. These components are an integral part of framing as a process, which consists of the following stages [7]:

- Frame-building. The creation of a frame results in the appearance of this frame in the text. This process includes the constant interaction of journalists with elites and social movements, which results in the appearance of new frames or activation of the old ones;

- Frame setting. Frame setting implies an interaction between the media frame and existing knowledge and predispositions of an individual. Due to activation of certain cognitive schemes, new frames are adopted more easily and have a longer-lasting effect;

- Individual and societal consequences of framing. Depending on the level of functioning, framing is able to change the attitude towards the problem (individual level) or contribute to the formation of such processes as political socialization, decision-making and collective activity (social level) [7]

Tankard proposed the list of framing mechanisms, $i$. e., of focal points for identifying and measuring news frames, which includes the headlines, subheads, photos, photo captions, leads, statistics and charts, concluding statements and paragraphs, logos, source selection and quotes selection [10]. Thus, creation and indoctrination of a frame occurs not only at the level of text but involves a number of additional elements accompanying the information message.

Due to the ability of frames to be easily "handed from one person to another," mass media often use frames that emanate from politicians, thus passing them on to the audience. Inside the society, active exchange of frames is also underway, which helps frames to spread among individuals fast, creating a noticeable effect in a short period. The most powerful frames are those that emanate from political actors and the media and are addressed to the citizens.

\section{Methods}

The empirical basis of this study is the materials of the final news releases of federal TV channels "Pervyi," and "Russia-1" ("Voskresnoye Vremya" and "Vesti Nedeli") in the period from November 24, 2013, to November 23, 2014. According to the leading public opinion research centers, these channels are the most popular among Russian viewers [11]. The use of this chronological framework is due to the political events that took place during this period and played an important role in the economic and political development of Russia. Among them, we can distinguish the beginning of Ukrainian crisis, Winter Olympics in Sochi, entry of Crimea into the Russian Federation, the imposition of sanctions against Russia and counter-sanctions, the crash of Malaysian Boeing in the Donetsk People's Republic. With the use of quantitative and qualitative content analysis, 1,300 news stories were analyzed, of which 739 are from "Pervyi" TV channel, and 561 are from "Russia-1" TV channel. For representativeness, all the stories covered in the final news releases were used, regardless of their political implications.

The qualitative content analysis within the framework of this study was performed with the use of Public.Ru Information Analysis System (IAS), which has services for search, collecting, processing, and storing of information, is equipped with sophisticated data query language and multifunctional interface. With the help of this system, an array of data was created, which includes the headlines of the newscasts and complete scripts of the news releases, which were used for further search of frames in the texts.

\section{Results}

The study established that out of 1,300 news stories, 441 do not have any strongly marked frame (34\%), being standard information messages (Table 1). According to the results of the quantitative content analysis, the share of messages with frames on "Russia-1" TV channel is higher than on "Pervyi" TV channel, making up to $77 \%$ of the total number of messages published in "Vesti 
Nedeli". Messages which include frames on "Pervyi" channel constitute $58 \%$ of the total number of messages.

Table 1. Number of news on "Pervyi" and "Russia" TV channels.

\begin{tabular}{|l|c|c|c|}
\hline & $\begin{array}{c}\text { Number of } \\
\text { news on } \\
\text { "Pervyi" TV } \\
\text { channel }\end{array}$ & $\begin{array}{c}\text { Number of } \\
\text { news on } \\
\text { "Russia" TV } \\
\text { channel }\end{array}$ & Total \\
\hline With frames & $426(58 \%)$ & $433(77 \%)$ & $859(66 \%)$ \\
\hline $\begin{array}{l}\text { Without } \\
\text { frames }\end{array}$ & $313(42 \%)$ & $128(23 \%)$ & $441(34 \%)$ \\
\hline Total & 739 & 561 & 1300 \\
\hline
\end{tabular}

A total of 859 news items containing frames were found to have 1,149 frames, which indicates a high intensity of media influence on the process of perception of information broadcast by federal TV channels (Table 2).

Table 2. Number of frames in news.

\begin{tabular}{|c|c|c|c|}
\hline & "Pervyi" & "Russia" & Total \\
\hline $\begin{array}{c}\text { News with } \\
\text { frames }\end{array}$ & 426 & 433 & 859 \\
\hline $\begin{array}{c}\text { Number of } \\
\text { frames }\end{array}$ & 603 & 546 & 1.149 \\
\hline
\end{tabular}

The qualitative content analysis performed showed that frames could influence the legitimation of political power. The result of the content analysis performed represented comparison of the results of sociological studies that determine the level of approval of the president with the frequency of frames used in the final news releases of the federal media. According to opinion polls conducted by polling centers, the approval rating of President V. Putin underwent major changes during the period under review. Thus, according to the All-Russian Public Opinion Research Center (VCIOM), in November 2013 the rating was the lowest since February 2012, hitting bottom at 60\%; however, in early May 2014 it went up to $85.9 \%$, and by the end of August reached a record level of $87 \%$.

According to the data published on the official website of the Public Opinion Foundation (FOM), the valuation of V. Putin's presidency in November 2013 was even lower and was $51 \%$, but then the rating went up, reaching the peak of $84 \%$ by the fall of 2014 .

As a result of the quantitative content analysis, it can be concluded that the dynamics of the level of approval of the president's activity depends on the frequency of use of media frames in news releases. For perception convenience, the results of the qualitative content analysis are visualized and presented in the form of two graphs in the same reference plane (Figure 1).

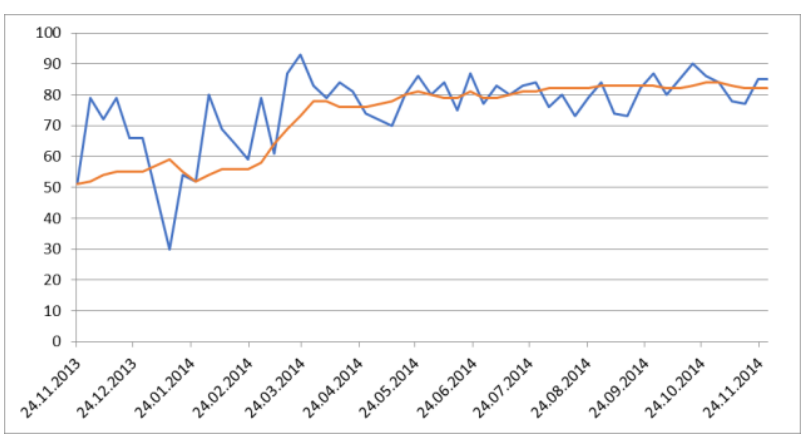

Fig. 1. The correlation between the approval rating and the frequency of frame used in news.

The chart above shows that the increase in the number of frames in the news is followed by the growth of the approval level for the activities of the Russian president V. Putin. The effect of using frames comes with a week's delay, e. g., one week after the increase in the number of frames in the release to $93 \%$ of all the news (the result of 23.03.14), the approval rating of the president's activity went up to reach $78 \%$ (the result of 30.03.14). Also, the observed relative stability in the dynamics of the rating after its sharp increase indicates a cumulative nature of the influence of frames on the rating. The quantitative content analysis showed that the frames used by the media in the presentation of the news could increase the level of approval of the government activities. Also, five main frames were revealed which are regularly found in news releases, and several additional ones, which are less frequent and mostly complement the more popular frames.

The most frequently used frames on both "Pervyi" and "Russia-1" were the frames of "the Great Power," "Ineptitude of Other Countries," "Confrontation / Opposition," "International Intervention," and "the Strong Leader." Also, to a lesser extent, the frames present included "demonization / discrediting of the USA", "groundless accusations", "state support", "protection of interests", "resorting to history".

The existence of each frame is conditioned by certain elements included into that frame. Let us examine the qualitative components of each frame in more detail.

"The Great Power" The "Great Power" frame distinguished in the analysis is present to the equal extent in news releases of "Pervyi" channel and «Russia24" channel and is the most commonly used frame. This frame is composite and includes several characteristics found in television reports. Among its constituent elements, it is possible to distinguish "unity of the people", "traditional values", "dependence on Russia", "triumph of Russia", "new Russia", "high level", "constant development", "Russia's attractiveness", and many others.

In TV stories, Russia is shown as a rapidly developing independent country, the "new Russia." A certain number of materials that make up a summary news release illustrate the power and grandeur of Russia with the help of epithetized descriptions of its military equipment and the high combat readiness: "These highprecision weapons are modern and include intelligent systems and control systems, as well as delivery and 
extermination systems. All that makes it extremely effective."

One of the components of the "Great Power" frame is loyalty to traditional values: "Russia is the country of traditional values that chooses its own path of development in the context of the global economic crisis." Often the news stories containing this frame are in the same news release with those pointing to the decadence of the EU and the US, which came as a result of the rejection of their traditional values.

The "Great Power" frame was widely used during the Olympics in Sochi, emphasizing the high level of not only the athletes representing Russia, but also of the technologies used to implement the cultural and sports programs, as well as the exceptional nature of the Russian Olympics, which was made possible due to the proper policy of the State: "The Olympics in Sochi ended with a grand and slightly sad closing ceremony. The true festival of sports, which went for two and a half weeks, is over. It is not only in the number of the medals that Russia won; as everyone noted it, it has held the best Olympics in history"; "All Russia rejoices. This is a triumph of our country."

This frame is also used to emphasize Russia's leadership as an economic and political player: "There will be competition, but in the past ten years Russia has developed a significant capacity which will help it to avoid being an outsider. I believe that we are the leaders in this race."

The greatness of the country is also emphasized by pointing at the dependence of other countries on Russia: "Only with Russia Europe may be strong," this can be considered a valedictory to the members of the next composition of the European Parliament." In the following quote, the "great power" frame is used in conjunction with the "international intervention" frame, which is an example of the use of several frames in one story: "Contracts are scuttled, many enterprises are on the verge of closure or have already stopped production. They call it there the result of the policy of sanctions against Russia imposed from Washington and Brussels."

The "Great Power" frame is characterized by the use of a large number of epithets in relation to Russia, i. e., "great", "new", "strong", "independent", or "merciful". In most cases, the frame appears in the news stories alone; however, it is also noticed in combination with such frames as "strong leader" and "international interference," which scales up the influence on the viewer.

"Ineptitude of other countries" This frame has also been widely used in the news stories of the two most popular Russian TV channels. The negative connotation in the name of this frame is explained by its contents aimed at discrediting the political power of the United States, the EU, and Ukraine. The frame is also shown through the prism of traditional values, reflecting a general decadency in the West: "Going back to Sweden, it's not surprising that there is now a significant growth in early age abortions, and early sex is widespread there, starting at the age of 9, and the problem is that at the age of 12 , there is also childhood impotence. A new challenge, the sophisticated Swedes say. Here they are, the European values in all their glory."

In a large number of cases, the "ineptitude" frame is found in the descriptions of the Ukrainian crisis, and the journalists select expressive vocabulary: "This week Ukraine celebrated an anniversary of EuroMaidan. Some are still happy that it happened, while others curse Maidan. The West failed to establish a new life in Ukraine. The situation in the country is disastrous", "Gangsters came to power. Those who seized power with weapons in their hands cannot be called a government."

The frame is also used for specific individuals, in particular, in respect of the US President Barack Obama, to describe his ineptitude as a leader. The authors of messages use various artistic devices, including sarcasm: "As a result, the Democrats declare, the elections became a referendum, as the Americans de facto voted not for the party but against the policy of the current president. According to one of the candidates who lost the elections in their state, one can complain about bad posters and poor advertising, but there is a component that predetermined the result, which was anger and disappointment. Americans are fed up with donkeys in power."

It is worth noting that the news aimed at discrediting the US president is often placed in the news release next to the news containing the "strong leader" frame used in respect of the Russian President V.V. Putin.

"International intervention" The frame of "international intervention" was found in news reports related to the crisis in Ukraine, the Crimea's entry into Russia, the Syrian conflict, and the publication of secret documents by E. Snowden. In most cases, this frame is used independently, however, in some stories on "Pervyi" channel, in order to generate stronger effect, it is used together with the frames of "confrontation" and "demonization of the USA", whereas on "Russia-1" TV channel it is used together with the "strong leader" frame.

In some cases, when the frame is used in respect of the United States, the accusation of "international intervention" is aimed not just at the government structures, but at Barack Obama personally: "On October 3, US Vice President Joe Biden confirmed that Europe opposed sanctions against Russia, but the US and Barack Obama personally insisted that the EU take the measures which were obviously disadvantageous for it. That is, it was the Americans who bent the Old World across its knee."

Messages containing this frame are found to use some deliberately hyperbolized expressions: "In the US capital, like in many other cities in the country, there is China Town; Washington's presence in China, primarily in Hong Kong, may not be so visible but is much more pervasive and explosive for the political system of China. This is an established network of the so-called non-governmental organizations which have noble missions: they are supposed to support democracy, human rights, and freedom. In fact, those are government organizations", as well as extreme evaluations: "Now America is a symbol of overreach 
both within the country and around the world. Anything goes, from wiretapping the phone lines of even the heads of allied states to harassing business corporations and entire countries in order to force them to abandon a particular business, be it the South Stream or the French Mistrals for Russia. The examples of the American overreach are abundant: from financing terrorists to embezzling the gold reserves of the countries that trusted the United States."

Also, the texts use some assumptions that are not supported by facts but express the likelihood of international intervention against Russia, thereby creating an imaginary threat to the sovereignty and the citizens of the country: "The fact that it is Western countries which were behind the coup in Kiev and supported those who came to power, as a result, has long been obvious. The US invested $\$ 5$ bn into the preparation of the putsch. There is also virtually no doubt that Washington and its satellites also have military plans in respect of Ukraine. And these plans are against Russia".

Despite its negative connotation, this frame is able to influence the process of political power legitimizing as strongly as the "great power" frame. The discrediting of the heads of the states that are currently not Russia's allies supports the legitimation of possible aggressive and controversial actions or statements on the part of Russia that would not find justification in case of a different presentation.

"Confrontation / Opposition" The "confrontation" frame, as it has been mentioned, can be used with the "international intervention" frame; however, in most cases, it is used independently and most often occurs in news stories related to the Ukrainian crisis. Expressing the tension in Russia's relations with the EU and the US, this frame provides opportunities to show Russia as heroic.

"Confrontation" is found in the texts of news stories in the form of a reference to a one-sided information war waged against Russia amid the Ukrainian events: "Since the beginning of the crisis in Ukraine, Western media coverage of the position of Russia and President Vladimir Putin has been almost exclusively negative. As a result of all that, in Germany the largest newspapers, $\mathrm{TV}$, and radio stations were deluged with angry letters from dissatisfied Germans", "Only when they arrived in Russia did they see that TV can tell the truth about what is happening in Slaviansk, where they come from."

In the news stories that are unrelated to the current political events and do not include references to direct or indirect interaction between the US and Russia, the "confrontation" frame is also present; it appears through the use of contrasting: "The Russians are good people. They left us everything they had brought here, everything that they had built. But the Americans are real exploiters; they will leave nothing to us", the Afghans say. "We will be happy if the Russians come to our motherland." Things will be in order then. They will bring help", "The victory of Modi is bad news for the United States, the country which has sanctions imposed against him since long ago and has so far denied him an
American visa. However, Obama has already rushed to call Modi and invite him to the US."

In the context of the political events that took place during the period under review, this frame has a special power of influence over the audience, while simultaneously displaying aggression directed at Russia and Russia's defensive position 00 and creating a field for political maneuvers.

"Strong leader". Another frame aimed at political power legitimizing includes elements that represent various qualities of an exemplary leader. The study showed that the descriptions within the "strong leader" frame most often include such elements as "under the president's personal control", "prompt decision", "closeness to the people" and "mercy", and this frame is also characterized by a large number of epithets and metaphors in the text of the news.

Stressing the unity of the people in a news story also provides a reference to the strength of the leader and his appropriate policy, and the authors of news messages often resort to the use of ratings: "Meanwhile, in the Crimea, we extract water and build pipelines for it, solve transport problems and tune up a new life. Moscow does not make a fuss but closely observes the progression of events around. Meanwhile, the Russian society is more united than ever. The level of Putin's support is at a record height of $86 \%$ !", "The appeal of the authorities of the Autonomous Republic of Crimea to Putin is understandable. He is a strong politician known for always taking into account the common man's needs and aspirations. According to a recent poll held by the AllRussian Public Opinion Research Center, his rating in Russia is now $68 \%$, which is a record high for nonelection time".

The use of ratings in combination with the opposition "Putin-Obama" has a dual effect: in addition to direct legitimization of the political power in Russia, the delegitimization of the US political power takes place: "Putin, in fact, does not curse anyone, unlike Obama, he does not resort to personal attacks, he is tactful and considerate with the Europeans. He does not react to the sanctions. He talks to everyone on the phone politely and even writes letters to his colleagues, warning them of the risks in advance. This is ideal. And the $86 \%$ support for Putin at home is due to the fact that people appreciate the dignity of Russia and understand how important it is to defend our right to our own civilization."

The authors of news stories emphasize the exclusivity of the Russian president, pointing to his endurance and openness, and use various epithets to enhance the effect: "It is already a tradition that this is a four-hour format for the summary of the year, with more than a thousand journalists in the whole and the indispensable live television broadcasting. None of the current world leaders is able of doing this. The difference of this year is that Putin looked warmer than the last time, calmer, more precise, and, therefore, more confident. The amazing Russian word is appropriate here, which means "more humane."

Due to the fact that the political power legitimization that has established itself in Russia pertains to the charismatic type, this frame is able to exert a strong 
influence on the trust rating of the president, which, in turn, justifies the high rating of $\mathrm{V}$. Putin during the events that have a negative impact on the economic and political situation in Russia (sanctions against Russia, imposition of embargo, collapse of the ruble, etc.).

\section{Conclusion and discussion}

The findings of this study clearly show that media framing is actively used by leading state TV channels as a technology for legitimizing the political power. As the political power legitimization that has established itself in Russia pertains to the charismatic type, a large amount of the news on the agenda focus on the political and nonpolitical activities of the Russian president. Based on the research conducted by VCIOM, FOM, and Levada Center, it can be stated that the information broadcast by the media, including that which uses framing, has a great influence on public opinion and is perceived by society as reliable.

It should be noted that the frames used on different channels are in parallel with each other, which reinforces the impact. One of the ways to enhance the effect is the use of several media frames within the same story.

In the course of the research it was proved that the frequency of frames used in the media influences the level of approval of the Russian president's activities, which indicates the important role of framing in the process of political power legitimization. A qualitative content analysis of news releases made it possible to identify the set of frames used by000 federal media. The most common among them are "the Great Power," "Ineptitude of Other Countries," "Confrontation / Opposition," "International Intervention," and "the Strong Leader."

These frames are reflected in the news releases through the use of a large number of metaphors, epithets, comparisons, litotes, and hyperboles, and expressive vocabulary. To achieve the greatest emotional impact, such techniques as parceling, sarcasm and irony are also used. It should be noted that framing analysis, as a kind of qualitative content analysis, has great prospects. Due to the active use of frames in the media, propaganda materials and commercials, it is possible to find more and more elements that can create framing effect, among which one can distinguish artistic techniques, the placement of an information message in a news release, accompanying materials, the lead-in by the newsreader, the heading, etc.

\section{References}

1. W. L. Bennett, S. Iyengar, Journal of Communication 58(4), 707-731 (2008)

2. M. A. Cacciatore, D. A. Scheufele, S. Iyengar, Mass Communication and Society 19(1), 7-23 (2016)

3. D. Chong, J. N. Druckman, Annu. Rev. Polit. Sci. 10, 103-126 (2007)

4. D. Chong, J.N. Druckman, American Political Science Review 101(04), 637655 (2007)
5. J.P. Cornelissen, M.D. Werner, The Academy of Management Annals 8(1), 181-235 (2014)

6. P. D’Angelo, J.A. Kuypers, Doing news framing analysis: Empirical and theoretical perspectives (Routledge, New York, 2010)

7. C.H. De Vreese, Information Design Journal \& Document Design 13(1), 51-62 (2005)

8. R.M. Entman, Journal of communication 43(4), 5158 (1993)

9. S.D. Reese, O.H. Gandy, A.E. Grant, Framing public life: Perspectives on media and our understanding of the social world (Routledge, New York, 2010)

10. J.W. Tankard Jr, The empirical approach to the study of media framing. In Framing public life: Perspectives on media and our understanding of the social world (Routledge, New York, 111-121, 2010)

11. T. Gitlin,. The whole world is watching: Mass media in the making and unmaking of the new left (Univ of California Press, Berkley, 2003)

12. K. Hallahan, Journal of public relations research 11(3), 205-242 (1999)

13. R.M. Entman, Journal of communication 41(4), 627 (1991)

14. R.M. Entman Democracy without citizens: Media and the decay of American politics (Oxford University Press, New York, 1989)

15. Obshhestvennoe mnenie 2014. (Levada-Centr, Moscow, 2015) 